Kontinu: Jurnal Penelitian Didaktik Matematika

E-ISSN: 2656-5544

Vol.3, No.1, Mei 2019

\title{
Profil Intuisi Matematis Siswa dalam Pemecahan Masalah Matematika \\ Ditinjau dari Gaya Kognitif Field Independent dan Field Dependent
}

\author{
Bondan Wicaksana Asmi Asmara'), Dian Septi Nur Afifah ${ }^{2)}$ \\ IAIN Tulungagung ${ }^{1)}$, IAIN Tulungagung ${ }^{2)}$ \\ Email korespondensi : Bondanwicaksana4896@gmail.com
}

\begin{abstract}
Abstrak. Penelitian ini dilakukan di SMPN 1 Watulimo. Subjek penelitian ini adalah 2 orang siswa kelas VII yang terdiri dari 2 orang dari masing-masing gaya kognitif. Pengumpulan datadilakukan dengan cara observasi, wawancara dan dokumentasi. Validitas data menggunakantriangulasi teknik. Teknik analisis data dilakukan dengan cara: (1) mengelompokkan data dalam4 kategori: (a) menganalisis dan memahami masalah (b) merancang dan merencanakan solusi (c)mengeksplorasi solusi untuk masalah yang sulit (d) memverifkasi solusi, kemudian mereduksidata yang tidak termasuk dalam 4 kategori tersebut, (2) menyajikan data dalam bentuk teksnaratif, dan (3) menyimpulkan profl intuisi siswa pada masing-masing kategori. Hasil penelitianini menunjukkan bahwa profl intuisi siswa dalam pemecahan masalah matematika untuk gayakognitif (1) siswa Field Independent: (a) memahami menganalisis masalah menggunakan intuis afrmatori yang bersifat langsung dengan cara membaca dan mengubah informasi kedalam bentukgambar dan melihat soal untuk mengetahui yang ditanyakan, (b) merancang dan merencanakansolusi menggunakan intuisi antisipatori yang bersifat global, (c) mengeksplorasi solusi untukmasalah yang sulit tidak menggunakan intuisi, menggunakan cara sesuai perencanaan yang dibuat,(d) memverifkasi solusi tidak menggunakan intuisi, memeriksa jawaban dengan mengecek rumusyang digunakan dan menghitung kembali jawaban yang telah diperoleh. (2) siswa Field Dependent:(a) memahami dan menganalisis masalah menggunakan intuisi afrmatori yang bersifat langsung,mengalami kesulitan dalam menentukan apa yang ditanyakan, (b) merancang dan merencanakansolusi menggunakan intuisi antisipatori yang bersifat global, meskipun dapat membuat rencanadalam mencari solusi namun tidak sampai solusi akhir, (c) mengeksplorasi solusi untuk masalahyang sulit tidak menggunakan intuisi, menggunakan cara sesuai dengan yang direncanakan, (d)memverifkasi solusi tidak menggunakan intuisi, menghitung kembali jawaban yang telah diperolehdengan cara yang sama.
\end{abstract}

Kata kunci:Profil, Intuisi, Gaya Kognitif Field IndependentField Dependent

\begin{abstract}
This research was conducted at SMPN 1 Watulimo. The subjects are students of class 2 VII consisting of two people from each of the cognitive styles. The data collection is by observation, interview, and documentation. The validity of the data using triangulation techniques. Data analysis technique conducted by: (1) collection data in four categories: (a) analyze and understand the problem (b) designing and planning solution (c) explore solutions to diffcult problems (d) verify the solution, then reduce the data are not included in four categories, (2) explaining data with narrative text, and (3) concluded intuition profles of students in each category. The results of this study indicate that the profle intuition students in mathematical problem solving for cognitive style (1) Field Independent students: (a) understand analyze problems using intuition affrmatory
\end{abstract}




\section{Kontinu: Jurnal Penelitian Didaktik Matematika \\ E-ISSN: 2656-5544 \\ Vol.3, No.1, Mei 2019}

that are directly by reading and changing the information in the form of pictures and look about to fnd out who asked, (b) designing and planning solutions using intuition anticipatory that is global, (c) explore solutions to diffcult problems are not using intuition, using suitable means plans made, (d) verify the solution does not use intuition, check the answer by checking formula used and recalculated the answers that have been obtained. (2) Field Dependent student: (a) understand and analyze problems using intuition affrmatory that is direct, experiencing diffculty in determining what is asked, (b) designing and planning solutions using intuition anticipatory global nature, although it can make a plan in the search for solutions but not until the fnal solution, (c) explore solutions to diffcult problems are not using intuition, using the system as planned, (d) verify the solution does not use intuition, recalculating the answers that have been obtained in the same manner.

Keywords: Profile, Intuition, Cognitive Style Field Independent Field Dependent

\section{PENDAHULUAN}

Proses pendidikan merupakan sebuah proses yang dengan sengaja dilaksanakan semata-semata bertujuan untuk mencerdaskan. Melalui proses pendidikan akan terbentuk sosok-sosok individu sebagai sumber daya manusia yang akan berperan besar dalam proses pembangunan bangsa dan negara. Oleh karena itu peran pendidikan demikian sangat penting sebab pendidikan merupakan kunci utama untuk menciptakan sumber daya manusia yang berkualitas. $^{1}$

Hubungan antar proses pendidikan dengan terciptanya sumber daya manusia merupakan suatu hubungan logis yang tidak dapat dipisahkan. Hal ini sesuai dengan pengertian pendidikan itu sendiri. Mc. Donald memberikan rumusan tentang pendidikan : “. . is a process or an activity which is directed at producing desirable in the behavior of human beings. ${ }^{2}$ Pendidikan adalah suatu proses atau kegiatan yang bertujuan menghasilkan perubahan tingkahlaku manusia. Secara sederhana, perubahan tingkah laku yang terjadi disebabkan oleh terjadinya perubahan pada tiga unsur meliputi unsur kognitif, afektif dan psikomotor ( Taksonomi Bloom ).

1 Sintong Silaban (ed.). 1993. Pendidikan Indonesia Dalam Pandangan Lima Belas Tokoh Pendidikan Swasta, Bagian IV, Jakarta: Dasamedia Utama, h., 65

2Mc. Donald. 1995. Education Psychology, San Francisco: Wadsworth Publising Company, Inc.h.4-6 
Kontinu: Jurnal Penelitian Didaktik Matematika

E-ISSN: 2656-5544

Vol.3, No.1, Mei 2019

Pendapat lainnya, yaitu pendapat Mc. Donald yang didalammnya sejalan dengan pendapat Winarno Surakhmad yang mengemukakan bahwa : Pendididkan atau dipersempit dalam pengertian pengajaran, adalah satu usaha yang bersifat sadar tujuan, dengan sistematis terarah pada perubahan tingkah laku. Menuju ke kedewasaan anak didik. Perubahan itu menunjuk pada suatu proses yang harus dilalui. Tanpa proses itu perubahan tidak mungkin terjadi, tanpa proses itu tujuan tak dapat dicapai. Dan proses yang dimaksud di sini adalah proses pendidikan. ${ }^{3}$

Undang-Undang Republik Indonesia Nomor 2 Tahun 1989, menyebutkan bahwa : "Pendidikan adalah usaha sadar untuk menyiapkan peserta didik melalui kegiatan bimbingan, pengajaran, dan/atau latihan bagi peranannya di masa yang akan datang." 4

Dari beberapa pengertian tentang "pendidikan" sebagaimana dikutif tersebut di atas sangat jelas bahwa pendidikan suatu kegiatan dalam upaya untuk mengubah tingkah laku objek didik ke arah positif. Pendidikan merangkum segisegi intelektual, afektif dan psikomotorik manusia, juga menyentuh cipta rasa dan karsa. Pendidikan juga merangsang pikiran-pikiran, perasaan dan kehendak manusia untuk bertindak secara bijaksana dengan mempertimbangkan lingkungan.

Matematika menurut Russeffendi adalah bahasa simbol, ilmu deduktif, yang tidak menerima pembuktian secara induktif, ilmu tentang pola keteraturan, dan struktur yang terorganisasi. ${ }^{5}$ Sejalan dengan pendapat tersebut, James dan James dalam kamus matematikanya mengatakan bahwa matematika adalah ilmu tentang mengenai bentuk, susunan besaran, dan konsep-konsep yang berhubungan satu dengan yang lainnya dengan jumlah yang banyak yang terbagi ke dalam tiga bidang yaitu aljabar, analisis dan geometri. ${ }^{6}$ Jadi matematika merupakan ilmu yang

3 Winarno Surakhmad. 1979. Metodologi pengajaran Nasional, Bandung: Jemmars, h. 13

4Undang-Undang Republik Indonesia, Nomor 2 Tahun 1989 tentang Sistem Pendidikan Nasional, pasal 1

5 Heruman, Model Pembelajaran Matematika di Sekolah Dasar,(Bandung: PT Remaja Rosdakarya, 2012), hal.1

6Erman Suherman, et. All.,Strategi Pembelajaran Matematika Kontemporer..., hal.16 


\section{Kontinu: Jurnal Penelitian Didaktik Matematika \\ E-ISSN: 2656-5544 \\ Vol.3, No.1, Mei 2019}

mempelajarai bahasa lambang atau simbol berupa angka-angka dan perhitungannya melaui metode bernalar dan berpikir.

Adapun secara rasional di dalam Al Qur'an telah tersirat ide mengenai matematika, salah satunya dalam Surat Al Fatir ayat 1 berikut.

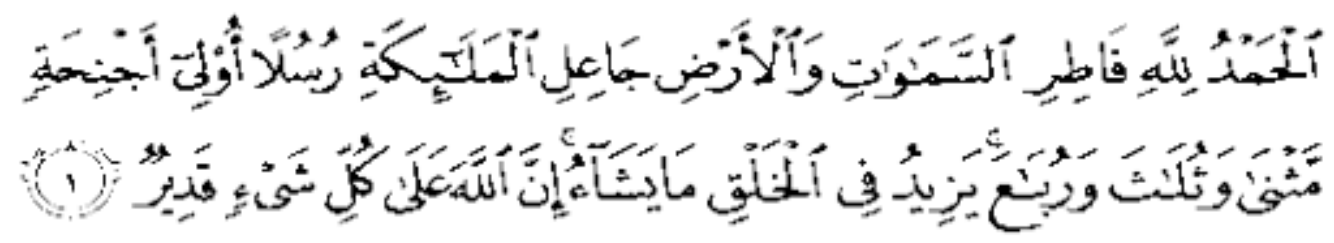

Artinya: Segala puji bagi Allah Pencipta langit dan bumi, yang menjadikan malaikat sebagai utusan-utusan (untuk mengurus berbagai macam urusan) yang mempunyai sayap, masing-masing (ada yang) dua, tiga, dan empat. Allah menambahkan pada ciptaan-Nya apa yang dikehendaki-Nya. Sesungguhnya Allah Maha Kuasa atas segala sesuatu.

Kegiatan pembelajaran matematika tentu tidak akan terlepas darimasalah matematika. Pemecahan masalah merupakan hal yang sangatpenting dalam pembelajaran matematika, kemampuan memecahkanmasalah merupakan hal penting yang harus dilatihkan pendidik kepadapara siswa. Melalui kegiatan memecahkan masalah, siswa dapatmenemukan aturan baru yang lebih tinggi tarafnya sekalipun siswamungkin tidak dapat merumuskannya secara verbal. ${ }^{7}$ Keterampilan sertakemampuan berpikir yang didapat ketika siswa memecahkan masalahdiyakini dapat ditransfer atau digunakan siswa tersebut ketikamenghadapi masalah di dalam kehidupan sehari-hari. Karena dalamkehidupan sehari-hari setiap siswa, pasti akan ada saat siswa dihadapkandengan suatu masalah.

Saat siswa dihadapkan pada masalah matematika yang menuntutuntuk segera ditemukan penyelesaiannya, mungkin saja siswa dapatmenyelesaikan masalah tersebut dengan segera. Siswa dapatmenyelesaikan suatu masalah dengan

7S. Nasution, Berbagai Pendekatan dalam Proses Belajar \& Mengajar, (Jakarta: Bumi Aksara, 2003), 173. 
Kontinu: Jurnal Penelitian Didaktik Matematika

E-ISSN: 2656-5544

Vol.3, No.1, Mei 2019

segera apabila mereka telahmemiliki pengetahuan dan pengalaman yang baik mengenai masalahtersebut. Sebaliknya ketika mereka mengalami kebuntuan dalammenyelesaikannya, tentu mereka akan cenderung berusahamenyajikannya dengan perantara atau model (yang berupa gambar,grafik, atau coretan-coretan lainnya) agar secara intuitif masalah tersebut mudah diterima dan dipahami. ${ }^{8}$ Pada kondisi seperti inilah kemampuanintuisi dipandang penting untuk dimiliki siswa, sebab intuisi akanmembantu siswa dalam melakukan lompatan pikiran ke arah pemecahanmasalah yang diinginkan. Argumen tersebut sesuai dengan pendapat Fischbein yang mengatakan bahwa intuisi dapat dijadikan sebagai“mediating cognitive". Dalam pengertian ini, intuisi dapat dijadikanjembatan pemahaman seorang siswa sehingga dapat memudahkan dalammengaitkan objek yang dibayangkan dengan alternatif solusi yang diinginkan. ${ }^{9}$ Dengan kata lain, intuisi mampu membantu menentukanstrategi atau langkah yang harus dilakukan untuk mencapai solusi suatupermasalahan.

Fischbein menjelaskan bahwa intuisi atau biasa disebut sebagaikognisi intuitif, selain berperan untuk membuat dugaan atau klaim dalamsuatu pemecahan masalah matematika, intuisi juga memainkan perandalam pemberian makna atau interpretasi informal terhadap suatudefinisi, teorema, rumus dan strategi penyelesaian tertentu. Dimanapenggunaan definisi dan teorema adalah ciri dari kognisi formal,sedangkan penggunaan rumus dan strategi penyelesaian adalah ciri dari kognisi algoritmik. ${ }^{10} \mathrm{Hal}$ ini menunjukkan bahwa intuisi mendukung perankognisi formal dan kognisi algoritmik dalam pemecahan masalahmatematis.

Secara umum, masalah matematika selalu identik dengan pencacahan dan perhitungan yang mempunyai hasil akhir yang bernilai pasti. Akan tetapi, matematika sebenarnya adalah sebuah ilmu yang menggabungkan logika dalam berpikir, berimajinasi, menganalisis, serta kemampuan menghitung. Hal ini terlihat dari begitu banyaknya cabang ilmu matematika yang menggabungkan

\footnotetext{
8Munir, “Model Penalaran Intuitif Siswa dalam Menyelesaikan Masalah Matematika" (Paper presented at Seminar Nasional Matematika dan Pendidikan Matematika FMIPA UNY, Yogyakarta, 10 November 2012), 252.

9lbid, halaman 251.

10lbid, halaman 252.
} 
Kontinu: Jurnal Penelitian Didaktik Matematika

E-ISSN: 2656-5544

Vol.3, No.1, Mei 2019

seluruh kemampuan tersebut,misalnya statistika, matematika diskrit, matematika kombinatorik, analisis, aljabar, teori bilangan, matematika rekreasi, dan lain-lain. ${ }^{11}$

Banyak faktor yang mempengaruhi individu dalam memecahkan masalah matematika, salah satunya adalah gaya kognitif. Gaya kognitif adalah karakteristik individu dalam penggunaan fungsi kognitif (berpikir, mengingat, memecahkan masalah, membuat keputusan, mengorganisasi dan memproses informasi, dan seterusnya) yang bersifat konsisten dan berlangsung lama. Gaya kognitif menempati posisi yang penting dalam proses pembelajaran. Bahkan gaya kognitif merupakan salah satu variabel belajar yang perlu dipertimbangkan dalam merancang pembelajaran. ${ }^{12}$ Sebagai salah satu variabel pembelajaran, gaya kognitif mencerminkankarakteristik siswa, disamping karakteristik lainnya seperti motivasi, sikap, minat, kemampuan berpikir, dan sebagainya.

Gaya kognitif merupakan cara seseorangmemproses, menyimpan maupun menggunakan informasi untuk menanggapi suatu tugas atau berbagai jenis lingkungannya. Dalam penelitianini, Peneliti memilih fokus pada tipe gaya kognitif Field Independent-Field Dependent. Perbedaan mendasar dari kedua gaya kognitif tersebut yaitu dalam hal bagaimana melihat suatu permasalahan. Berdasarkan beberapa penelitian di bidang psikologi, ditemukan bahwa individu dengan gaya kognitif Field Independent cenderung lebih analitis dalammelihat suatu masalah dibandingkan individu dengan gaya kognitif Field Dependent(Darma Andreas N N Nilawajan, 2013:73). Pada gaya kognitif Field Independent dan Field Dependent diduga mampu memecahkan masalah matematika. Hal tersebut dapat dilihatdari katakteristik yang dimiliki kedua gayakognitif tersebut. Karakteristik dasar dari keduagaya kognitif tersebut sangat cocok untukditerapkan dalam penelitian yang melibatkanproses berpikir dalam pemecahan masalahmatematika. Oleh karena itu akan sangatmenarik jika dilakukan penelitian mengenaigaya kognitif tersebut.

11Endah Dwi Purwantari dan Julan Hernadi, “Strategi Menyelesaikan Puzzle yang Memuat Aspek Matematika", Jurnal Prodi Pendidikan Matematika, FKIP, Universitas Muhammadiyah Ponorogo (2015), 1.

12Budi Usodo, "Profil Intuisi Mahasiswa Dalam Memecahkan Masalah Matematika Ditinjau Dari Gaya Kognitif Field Dependent dan Field Independe" (Paper presented at Seminar Nasional Matematika dan Pendidikan Matematika UNS, Semarang, 2011), 97. 
Kontinu: Jurnal Penelitian Didaktik Matematika

E-ISSN: 2656-5544

Vol.3, No.1, Mei 2019

Dalam penelitian inijuga akan dilihat intuisi peserta didik. Adapunhal tersebut menacu pada pendapat Fischbeindengan indikator (Budi Usodo,2012,3-4).

a. Affrmatory intuition (intuisi afrmatori)

Intuisi afrmatori dapat diartikan sebagaiintuisi yang berupa pernyataan, representasi, interpretasi, solusi yang secara individual dapat diterima secara langsung, selfevident, global dan cukup secara intrinsik.

b. Anticipatory intuition (intuisi antisipatori)

Intuisi antisipatori adalah intuisi yangmuncul ketika seseorang bekerja kerasuntuk memecahkan masalah, namun solusinya tidak segera diperoleh (tidak secaralangsung).

Berdasarkan permasalahan di atas, peneliti ingin mengetahui bagaimana Intuisi siswa dalam menyelesaikan masalah matematika, antara siswa dengan gaya kognitif Field Independent (FI) dan Field Dependent (FD). Adapun dengan demikian peneliti mengambil masalah tersebut sebagai bahan penelitian, dengan judul "Profil Intuisi Siswa Dalam Menyelesaikan Soal Matematika Ditinjau Dari Gaya Kognitif Field Dependent Dan Field Independent”.

\section{Rumusan Masalah}

1. Bagaimana profil intuisi siswa dengan gaya kognitif Field Dependent dalam menyelesaikan soal matematika?

2. Bagaimana profil intuisi siswa dengan gaya kognitif Field Independent dalam menyelesaikan soal matematika?

\section{Tujuan Penelitian}

1. Mengetahui profil intuisi siswa dengan gaya kognitif Field Dependent dalam menyelesaikan soal matematika?

2. Mengetahui profil intuisi siswa dengan gaya kognitif Field independent dalam menyelesaikan soal matematika?

\section{Kegunaan Penelitian}

1. Secara Teoritis

Peneliti berharap penelitian in I dapat memberikan deskriftif tentang proses berfikir siswa dalam memahami dan menyelesaikan soal matematika pokok bahasan Garis dan Sudut kelas VII SMP. Jika gambaran mengenai proses berfikir siswa dalam memahami dan menyelesaikan soal telah 
Kontinu: Jurnal Penelitian Didaktik Matematika

E-ISSN: 2656-5544

Vol.3, No.1, Mei 2019

diketahui oleh pendidik maka pendidik mampu melakukan perbaikan pada pembelajaran selanjutnya.

2. Secara Praktis

a. Bagi kepala SMP : Sebagai bahan pertimbangan dalam mengambil kebijakan yang berkenaan dengan pembelajaran matematika.

b. Bagi Guru : memberikan sumbangan pemikiran bagi guru matematika tentang pentingnnya analisis proses berfikir siswa dalam menyelesaikan soal matematika sehingga dapat meningkatkan pemahaman dan pengetahuan siswa terhadap pelajaran matematika.

c. Bagi Siswa : menumbuhkan semangat dalam diri siswa agar siswa lebih giat menyelesaikan soat - soal matematika sehingga dapat meningkatkan hasil belajar siswa.

\section{METODE PENELITIAN}

Penelitian dilaksanakan di SMPN 1 Watulimo pada semester genap 2017/ 2018. Alasan peneliti memilih SMPN 1 Watulimo sebagai tempat penelitian adalah sebagai berikut:

1. Sekolah memiliki data dan informasi yang di butuhkan untuk kepentingan penelitian.

2. Pada sekolah tersebut belum pernah dilakukan penelitian yang sejenis.

Berdasarkan masalah yang diteliti, maka penelitian ini dapat digolongkan kedalam penelitian kualitatif. Pada penelitian ini teknik pengambilan sampel yang digunakan adalah salah satu teknik pengambilan sampel Nonprobality Sampling yaitu purposivesampling.

Pada penelitian ini subyek yang digunakan adalah 4 orang siswa kelas VII SMPN 1 Watulimo semester genap tahun ajaran 2017/2018. Empat siswa tersebut terdiri dari 2 orang siswa bergaya kogntif Field Independent dan 2 siswa yang bergaya kognitif Field Dependent. Alasan memilih siswa kelas VII sebagai subyek penelitian karena pada kelas VII sudah dapat dilakukan penggolongan gaya kognitif, serta akan menjadi bekal untuk siswa dalam jenjang selanjutnya. Selain itu, siswa kelas VII merupakan peralihan dari sekolah dasar menuju tingkat 
Kontinu: Jurnal Penelitian Didaktik Matematika

E-ISSN: 2656-5544

Vol.3, No.1, Mei 2019

menengah sehingga akan sangat menarik jika dilakukan penelitian terhadap siswa tersebut.

Sebelum menentukan subyek penelitian, peneliti terlebih dahulu menyiapkan tes penggolongan gaya kognitif yang bersumber dari soal yang dibuat oleh Witkin. Peneliti menggunakan satu kelas untuk memberikan tes penggolongan gaya kognitif. Dari hasil tes tersebut, dipilih 2 orang siswa bergaya kognitif Field Independent dan 2 orang bergaya kognitif Field Dependent dengan meminta pertimbangan guru. Pertimbangan tersebut terkait dengan salah satu kriteria penentuan subyek yaitu dipilih siswa yang dapat mengungkapkan secara bagus.

Soal tes penggolongan gaya kognitif menggunakan Group Embedded Figure Test (GEFT) yang dibuat oleh Witkin. Soal tersebut menggunakan bahasa inggris sehingga harus diterjemahkan dalam bahasa Indonesia untuk mempermudah siswa dalam mengerjakan danmemahami soal tersebut. Soal penggolongan gayakognitif tersebut memiliki reliabilitas sebesar 0,82 sehingga soal tersebut sudah valid dan tidak perlu dilakukan validitas soal lagi. Pengumpulandata menggunakan observasi, dokumenasi, dan wawancara.

Analisis data kualitatif dalam penelitian ini dilakukan secara interaktif dan berlangsung secara terus menerus sampai tuntas dan didapatkan dataintuisi siswa. Aktivitas dalam analisis data, yaitu reduksi data, penyajian data, dan penarikan kesimpulan. Keabsahan data menggunakan triangulasi teknik yang berarti peneliti menggunakan teknik pengumpulan data yang berbeda-beda untuk mendapatkan data dari sumber yang sama.

\section{HASIL DAN PEMBAHASAN}

Berdasarkan tes penggolongan gaya kognitif dapat terlihat bahwa terdapat 7 siswa yang memiliki gaya kognitif Field Independent dan 8 siswa memiliki gayakognitif Field Dependent. Dari hasil tes tersebut akan diambil sampel untuk penelitian. Dari masing-masing gaya kognitif dipilih 2 orang siswa. Kriteria nilai yang digunakan adalah jika skor tes kurang dari 10 maka siswa tersebut memiliki gaya kognitif Field Dependent sedangkan jika skor yang diperoleh lebih dari 10 


\section{Kontinu: Jurnal Penelitian Didaktik Matematika}

\section{E-ISSN: 2656-5544}

\section{Vol.3, No.1, Mei 2019}

maka siswa tersebut memiliki gaya kognitif Field Independent. Dari hasil pertimbangan dipilih 4 orang siswa, yaitu siswa Field Independent pertama dan Field Independent kedua dengan gaya kognitif Field Independentdan siswa Field Dependent pertamadan Field Dependent kedua dengan gaya kognitif Field Dependent.

Data dalam penelitian ini berupa intuisi siswa dalam pemecahan masalah matematika, yang diperoleh dari hasil observasi, wawancara, dokumentasi, dan triangulasi. Berikut soal pemecahan masalah matematika:

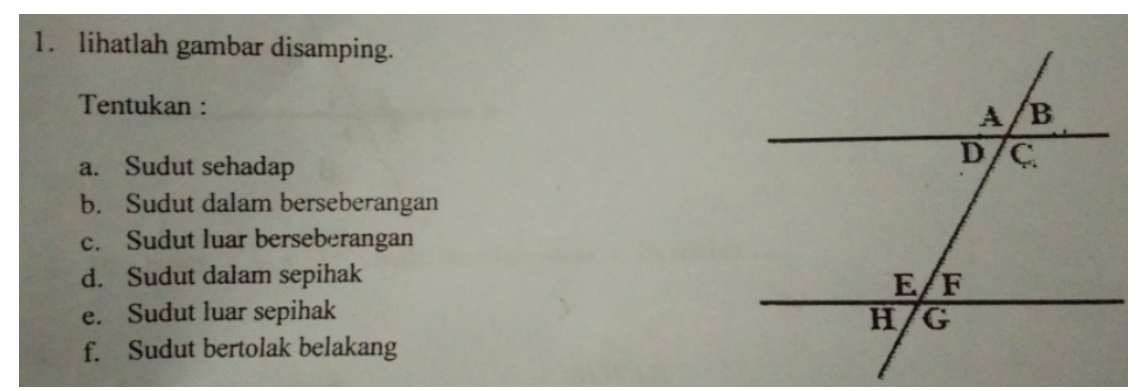

Gambar 1.1Soal yang di berikan kepada siswa

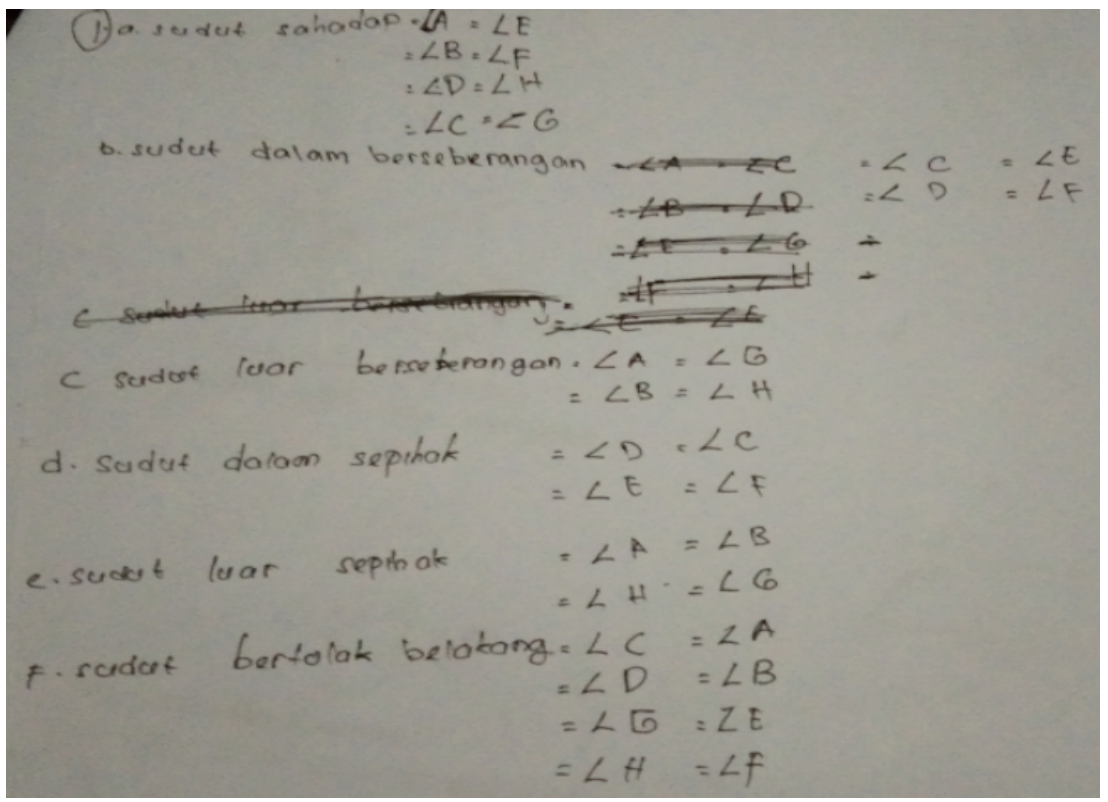

Gambar 1.2 Hasil pengerjaan siswa

\section{Siswa Field Independent}


Kontinu: Jurnal Penelitian Didaktik Matematika

E-ISSN: 2656-5544

Vol.3, No.1, Mei 2019

Berikut adalah kegiatan yang dilakukan siswa Field Independent selama mengerjakan soal :

a) Membaca sekilas soal yang diberikan oleh peneliti

b) Menuliskan biodata pada lembar jawaban

c) Membaca soal secara keseluruhan dari soal nomor satu sampai nomor dua

d) Menanyakan kepada peneliti mengenai soal pertama

e) Membaca soal berulang-ulang soal pertama

f) Menentukan sudut yang diminta

g) Menuliskan hasil yang diperoleh

h) Meneliti kembali hasil sudut yang dicari pada soalpertama

\section{Siswa Field Dependent}

Berikut ini adalah kegiatan yang dilakukan siswa Field Dependent selama mengerjakan soal :

a) Mengisi biodata terlebih dahulu pada lembar jawaban

b) Membaca soal pertama

c) Memperhatikan bagian yang ditanyakan dari soal

d) Menanyakan gambar kepada peneliti dan bagian yang ditanyakan

e) Mengamati gambar dari soal yang diberikan

f) Mencari sudut yang ditanyakan dari soal

g) Berhenti sejenak, kemudian memperhatikan kembali gambar yang terdapat pada soal

h) Mencoret-coret gambar pada lembar kerja dan tidak menggunakan lembar coretan

i) Memberi garis pada bagian luas yang ditanyakan

j) Mengalami kebingungan untuk mencari jawaban akhir dari pertanyaan pada soal pertama

k) Melanjutkan mengerjakan soal nomor dua

1) Menuliskan bagian yang diketahui dari soalkedua pada lembar jawaban

m) Menuliskan hasilnya

n) Menghitung kembali jawaban pada soal nomor satu

Setelah dilakukan analisis data, selanjutnya membandingkan hasil pengambilan data melalui observasi, wawancara dan dokumentasi. Dengan membandingkan tiga data dapat diketahui valid atau tidak data yang diperoleh. Berikut ini adalah tabel hasil analisis yangmenggambarkan intuisi yang digunakan siswa Field Independent dan siswa Field Dependent dalam pemecahan masalah matematika. 
Kontinu: Jurnal Penelitian Didaktik Matematika

E-ISSN: 2656-5544

Vol.3, No.1, Mei 2019

\begin{tabular}{|c|c|c|c|c|}
\hline \multirow{2}{*}{$\begin{array}{l}\text { Gaya kognitif } \\
\text { siswa }\end{array}$} & \multicolumn{4}{|c|}{ Intuisi yang digunakan } \\
\hline & $\begin{array}{l}\text { Menganalisis } \\
\text { dan memahami } \\
\text { masalah }\end{array}$ & $\begin{array}{l}\text { Merancang dan } \\
\text { merencanakan } \\
\text { solusi }\end{array}$ & $\begin{array}{l}\text { Mengeksplorasi solusi } \\
\text { untuk masalah yang } \\
\text { sulit }\end{array}$ & Memverifikasi solusi \\
\hline $\begin{array}{l}\text { Field Independent } \\
\text { Kedua }\end{array}$ & Intuisi afirmatori & Intuisi antisipatori & $\begin{array}{c}\text { Tidak menggunakan } \\
\text { intuisi }\end{array}$ & $\begin{array}{c}\text { Tidak menggunakan } \\
\text { intuisi }\end{array}$ \\
\hline $\begin{array}{c}\text { Field Dependent } \\
\text { Pertama }\end{array}$ & Intuisi afirmatori & Intuisi antisipatori & $\begin{array}{c}\text { Tidak menggunakan } \\
\text { intuisi }\end{array}$ & $\begin{array}{c}\text { Tidak menggunakan } \\
\text { intuisi }\end{array}$ \\
\hline
\end{tabular}

\section{Tabel 1. Hasil Analisis Intuisi Siswa Field Indepent dan Field Dependent}

Gaya kognitifsiswaIntuisi yang digunakanMenganalisisdan memahamimasalah Merancang dan merencanakan solusi Mengeksplorasi solusi untuk masalah yang sulit Memverifkasi solusi Field Independent Kedua Intuisi afrmatori Intuisi antisipatori Tidak menggunakan intuisiTidak menggunakan intuisi Field Dependent Pertama Intuisi afrmatori Intuisi antisipatori Tidak menggunakan intuisi.

\section{KESIMPULAN}

Berdasarkan hasil analisis dan pembahasan,maka dapat diperoleh kesimpulan sebagaiberikut.

\section{Profl Intuisi Siswa dengan Gaya KognitifField Independent}

a. Pada tahapan menganalisis dan memahami masalah intuisi yang digunakanadalah intuisi afrmatori yang bersifatlangsung. Siswa menerima langsunginformasi yang diterima dari soaldan mengubahnya kedalam bentukgambar.

b. Pada tahapan merancang dan merencanakan solusi intuisi yang digunakanadalah intuisi antisipatori yang bersifatglobal. Siswa mencermati informasisoal tersebut untuk memecahkan masalah sehingga yang ada dalam pemikirannya adalah ide global mengenaisoal tersebut.

c. Pada tahapan mengeksplorasi solusiuntuk masalah yang sulit siswa tidakmenggunakan intuisi. Siswa mengerjakan soal dengan menggunakan rumusdan cara sesuai dengan yang dirancangdan direncanakan sebelumnya.

d. Pada tahapan memverifkasi solusi siswa tidak menggunakan intuisi. Siswahanya memeriksa rumus yang telahditulis dan memeriksa jawaban.

\section{Profil intuisi pada siswa dengan gaya kognitif Field Dependent}


Kontinu: Jurnal Penelitian Didaktik Matematika

E-ISSN: 2656-5544

Vol.3, No.1, Mei 2019

a. Pada tahapan menganalisis dan memahami masalah intuisi yang digunakanadalah intuisi afrmatori yang bersifatlangsung. Siswa menerima informasidari soal secara langsung dengan caramembaca soal.

b. Pada tahapan merancang dan merencanakan solusi intuisi yang digunakanadalah intuisi antisipatori yang bersifatglobal.

c. Pada tahapan mengeksplorasi solusiuntuk masalah yang sulit siswa.

d. Tidak menggunakan intuisi. Siswamengikuti rencana yang telah dibuatsebelumnya.

e. Pada tahapan memverifkasi solusi siswa memverifkasi solusi siswa tidakmenggunakan untuisi. Siswa menghitung kembali jawaban yang telahdiperoleh dengan cara yang sama dantidak menggunakan cara lain untukmemeriksanya.

\section{DAFTAR PUSTAKA}

Bob Phiter, “An Aspect Of Vocational Teachers' Cognitive Style: Field Dependence-Field Independence”, Journal of Vocational Education Research, 2005.

Budi Usodo, "Profl Intuisi Mahasiswa DalambMemecahkan Masalah Matematika Ditinjau dari Gaya Kognitif Field Dependent dan Field Independent". Prosiding Seminar Nasional Matematika dan Pendidikan Matematika UNS, 2011.

Darma Andreas Ngilawajan, "Proses Berpikir Siswa Dalam Memecahkan Masalah Matematika Materi Turunan Ditinjau Dari Gaya Kognitif Field Independent dan Field Dependent”, Pedagogia. Program Studi Matematika Universitas Pattimura,Vol.2 No.1, 2013.

Endah Dwi Purwantari dan Julan Hernadi, "Strategi Menyelesaikan Puzzle yang Memuat Aspek Matematika”, Jurnal Prodi Pendidikan Matematika, FKIP, Universitas Muhammadiyah Ponorogo (2015), 1.

Erman Suherman, et. All.,Strategi Pembelajaran Matematika Kontemporer..., hal.16

Heruman, Model Pembelajaran Matematika di Sekolah Dasar, (Bandung: PT Remaja Rosdakarya, 2012), hal.1 
Kontinu: Jurnal Penelitian Didaktik Matematika

E-ISSN: 2656-5544

Vol.3, No.1, Mei 2019

Mc. Donald. 1995. Education Psychology, San Francisco: Wadsworth Publising Company, Inc.h.4-6

Munir, "Model Penalaran Intuitif Siswa dalam Menyelesaikan Masalah Matematika" (Paper presented at Seminar Nasional Matematika dan Pendidikan Matematika FMIPA UNY, Yogyakarta, 10 November 2012), 252.

Sintong Silaban (ed.). 1993. Pendidikan Indonesia Dalam Pandangan Lima Belas Tokoh Pendidikan Swasta, Bagian IV, Jakarta: Dasamedia Utama, h., 65

S. Nasution, Berbagai Pendekatan dalam Proses Belajar \& Mengajar, (Jakarta: Bumi Aksara, 2003), 173.

Undang-Undang Republik Indonesia, Nomor 2 Tahun 1989 tentang Sistem Pendidikan Nasional, pasal 1

Winarno Surakhmad. 1979. Metodologi pengajaran Nasional, Bandung: Jemmars, h. 13 